\title{
Quality Improvement of Cassava Flour of Local Variety of Ternate Through Fermentation Method (Application on Traditional Food of North Maluku "Sagu Lempeng")
}

\author{
Hamidin Rasulu \\ Department of Food Technology, Faculty of Agriculture, University of Khairun Ternate, North Maluku- Indonesia \\ E-mail: hamidinrasulu@yahoo.com
}

\begin{abstract}
Cassava is utilized as one of the main food substances in North Maluku society and it has potential for food diversification due to its special quality compare to other products. Cassava commodity can be processed into composite flours with fermentation methods and it is as prominent of food resources and has low of Cyanide content (HCN). This research used two phases of Program Random Completes; it used fermentation period of cassava with 5 levels: 24,36,48,60, and 72 hours. And the utilization phases of composite flours the making of sagu lempeng. The result of this research showed that with long period of fermentation had produce cassava flours with cyanide content of $16,41-56,93 \mathrm{ppm}$ with initial content of cyanide as big as $109,02 \mathrm{ppm}$. The highest cyanide content was found with fermentation period of 24 hours and lower fermentation of 72 hours. The characteristic of sagu lempeng with chocolate and orange taste has 0.72 and $0.55 \mathrm{~g}$ total fats, 1.05 and $0.57 \mathrm{~g}$ protein, 86.9 and $86.28 \mathrm{~g}$ total carbohydrate, 2.86 and $1.35 \mathrm{~g}$ rough standard fiber.
\end{abstract}

Keywords - cassava, fermentation, HCN, composite flours, sagu lempeng

\section{INTRODUCTION}

The utilization of cassava in North Maluku is considered high. It is indicated by the harvest area and production of crops by regency or municipality, especially for cassava, is 11,770 ha with average of production 34,621 ton/year, which is consumed directly by the society. Cassava is one of main food for North Maluku societies and is a potential food as food diversification in general [2].

Cassava plant contains gluco-cyanide in form of toxic aglicon that releasable through hydrolysis process by linamarase enzyme and resulting in hydrogen cyanide [1]. Direct consume of cassava can cause cyanogenesis that give dangerous toxic effect. $50 \mathrm{mg} / \mathrm{kg}$ ( $\mathrm{ppm}$ ) of cyanide content in the material is considered safe for consumption [3].

Traditional processing of cassava has proven to be able to reduce cyanide level by washing, submerging, cooking and drying the product to be processed as gaplek. Repeating washing and submerging processes can reduce cyanide content for $50 \%$ and level of starch in the cassava. Through drying process, the cyanide content in cassava can reduce until 1/16 of total cyanide [4].

The utilization of cassava material through fermentation technique to decrease the level of cyanide is needed. The result of the fermentation process will be further processed into cassava flour as the main raw material in the making of sagu lempeng, which is the traditional food of North Maluku society. The process can give value added to the local food in term of food security and diversification aspects. Sagu lempeng has comparative advantage than other foods due to its easy process and it can be keep for a long period.

\section{MATERIAL AND METHOD}

The main material used was cassava variety of Ternate $50 \mathrm{~kg}$. The material was obtained from crops farmers in Jaya Tidore Village. The method in making cassava flour resulting from fermentation process is started with peeling, washing, and fermentation with different time, grated, pressing, and drying processes.

Experiment design used in the research was completely randomized design arranged in factorial with two steps. The first step was the length of cassava fermentation with single factor consisted of 5 levels: 24, 36, 48, 60 and 72 hours of fermentation time. Every treatment was repeated 4 times; therefore there were 20 experimental unites. The second step was the utilization of the best cassava flour resulted from fermentation in the making of sagu lempeng. 


\section{A. The Experiment}

In the first step of experiment, cassava was sorted, peeled, washed, packed in a plastic bag for the period of fermentation, grated, pressing and dried. The second step was the making of flat sagu using flour resulted from the best result of cassava fermentation. The process was started with filtering, mixing, molding, and cooking to create sagu lempeng sheet. The next process was shortening the size and packing. Observation was conducted on the characteristics of cassava from local variety of Ternate before and after the fermentation. It consisted of cyanide level, degree of acidity and starch level. Observation on sagu lempeng product was conducted on starch level, protein level, rough fiber, total fat and texture.

\section{RESULT AND DISCUSSION}

Result from the analysis of material used in the making of cassava flour, which is local variety of cassava of Tidore is presented in Table 1 and 2.

TABLE I

THE CHARACTERISTIC OF LOCAL VARIETy CASSAVA OF TERNATE

\begin{tabular}{|l|c|}
\hline Parameter & Result of Analysis \\
\hline Cyanide (ppm) & 109,02 \\
Moisture (\%) & 59,06 \\
Starch konten (\%) & 28,15 \\
Crude fiber (\%) & 2,23 \\
Total sugar(\%) & 5,35 \\
pH & 5,71 \\
\hline
\end{tabular}

TABLE II

The Percentage of DeCREASe In Cyanide Level (\%)

\begin{tabular}{|c|c|c|c|c|}
\hline \multirow{2}{*}{$\begin{array}{l}\text { Fermentation } \\
\text { Period } \\
\text { (Hour) }\end{array}$} & \multicolumn{2}{|c|}{$\begin{array}{l}\text { Cassava after } \\
\text { Fermentation }\end{array}$} & \multicolumn{2}{|c|}{ Cassava Flour } \\
\hline & $\begin{array}{c}\text { Cyanide } \\
\text { Level } \\
(\mathrm{ppm} / \mathrm{bk})\end{array}$ & $\begin{array}{c}\text { Decrease }^{*} \\
(\%)\end{array}$ & $\begin{array}{c}\text { Cyanide } \\
\text { Level } \\
(\mathbf{p p m} / \mathbf{b k}) \\
\end{array}$ & $\begin{array}{c}\text { Decrease }^{* *} \\
(\%)\end{array}$ \\
\hline 24 & 222,37 & 16,49 & 62,66 & 71,82 \\
\hline 36 & 196,12 & 53,65 & 53,65 & 72,64 \\
\hline 48 & 122,67 & 35,06 & 35,06 & 71,42 \\
\hline 60 & 78,90 & 24,87 & 24,87 & 68,48 \\
\hline 72 & 59,45 & 17,64 & 17,64 & 70,33 \\
\hline
\end{tabular}

Note : (*) From the cyanide level of fresh cassava $(266,29 \mathrm{ppm} / \mathrm{bk})$

(**) From the cyanide level of cassava after fermentation

\section{A. Characteristics of Cassava after Fermentation}

Decrease in cyanide content after fermentation process of cassava. The average of highest cyanide level was found in a treatment of fermentation period of 24 hours of 222.37 $\mathrm{ppm} / \mathrm{bk}$. The lowest cyanide level was found in a treatment of period fermentation of 72 hours of 59.45 ppm/bk (Fig. 1).

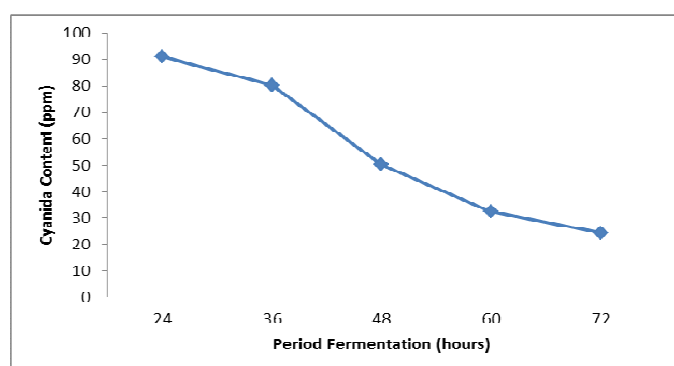

Fig. 1. Cyanide level of cassava after fermentation due to the period of fermentation treatment

\section{B. Characteristic of Cassava Flour after Fermentation Cyanide Level}

The average of highest cyanide level was indicated by cassava flour treated with period of fermentation of 24 hours, which is $62.66 \mathrm{ppm} / \mathrm{bk}$. The lowest level of cyanide obtained with treatment of period of fermentation of 72 hours, which is $17.64 \mathrm{ppm} / \mathrm{bk}$. Level of cyanide in cassava flour tends to decrease with the increase in the period of fermentation process (Fig.2)

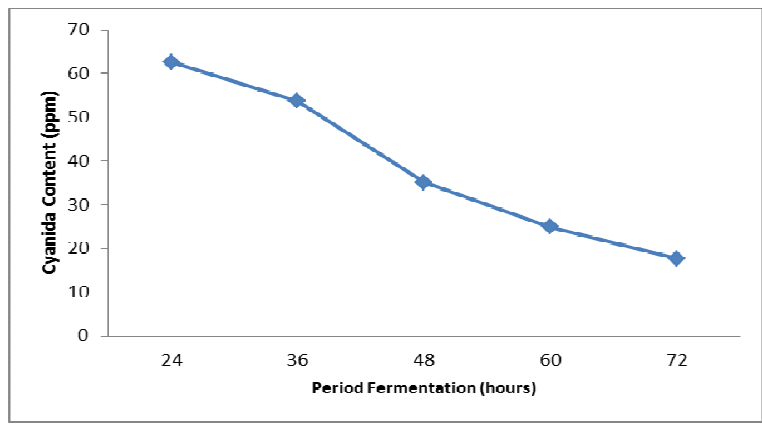

Fig. 2. Cyanide level of cassava flour after fermentation due to the period of fermentation treatment

\section{Level of Starch}

Cassava is one of commodities having highest starch content. Research result found that level of starch of cassava flour ranges from $48.37 \%-62.48 \%$ Fig. 3 .

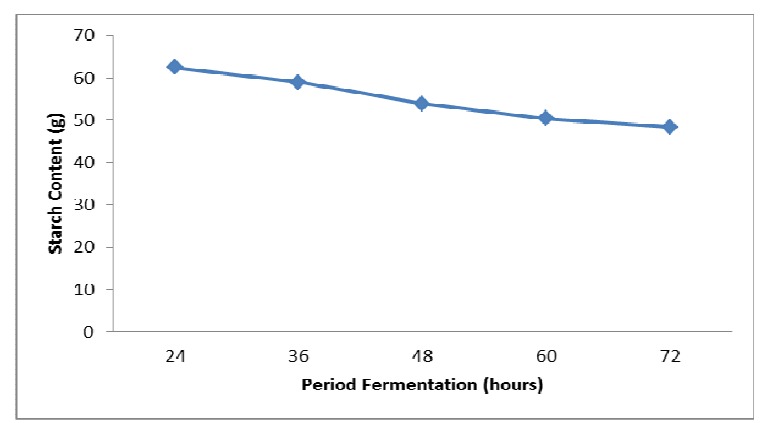

Fig.3. Level of starch of cassava flour after fermentation due to the period of fermentation treatment

TABLE III

CHARACTERISTIC OF SAGU LEMPENG QUALITY

\begin{tabular}{|c|c|c|}
\hline \multirow{4}{*}{ Parameter } & \multicolumn{2}{|c|}{ Sagu lempeng } \\
\hline & \multicolumn{2}{|c|}{ Nutrient Level } \\
\hline & Serving: $100 \mathrm{~g}$, & Calorie: 358 \\
\hline & Level & $\% \mathrm{AKG}^{*}$ \\
\hline Total Fat & $0,72 \mathrm{~g}$ & 1,11 \\
\hline Total Protein & $1,05 \mathrm{~g}$ & 2,10 \\
\hline Total Carbohydrate & $86,9 \mathrm{~g}$ & 28,97 \\
\hline Crude Fiber & $2,86 \mathrm{~g}$ & - \\
\hline Texture & $22,3 \mathrm{~N}$ & - \\
\hline
\end{tabular}

*The percentage of nutrient level was based on 2000 calorie of diet.

Sagu lempeng is made from cassava flour resulted from fermentation of half wet or half dry cassava (Fig. 4)

The tuber of local variety cassava of Tidore has dark brown color and its tuber flesh is white. The average cyanide level of the cassava is $266.29 \mathrm{ppm} / \mathrm{bk}$, which is more than > $100 \mathrm{pm}$; therefore, it belongs to bitter cassava group. The level of cyanide in the cassava is considered high and 
exceeds the safe level for consumption; therefore direct consumption can be toxic. Fermentation process in the research was expected to be able to reduce the level of cyanide in the raw material up to safe level.

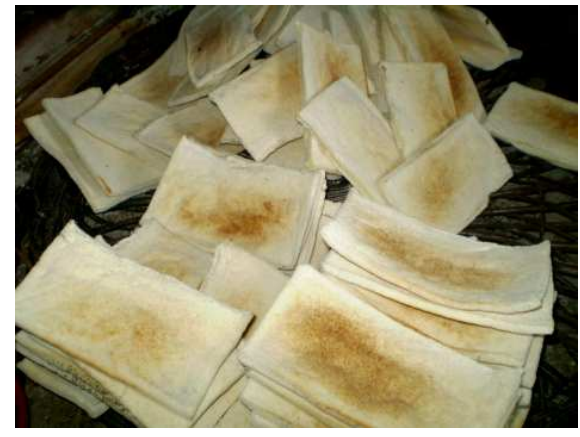

Fig. 4. Product Sagu Lempeng, Food Traditional North Maluku

The smaller the size of raw material the lower is the level of cyanide in the cassava after the fermentation. The reason is the smaller the size the bigger is the surface area; thus, the contact of linamarase with linamarin is faster. With faster enzyme activity in the breakdown of linamarin, the number of cyanide acid $(\mathrm{HCN})$ released is bigger; therefore the number of cyanide in the raw material is low [3].

Longer fermentation shows decrease in cyanide level. It is means that pressing and drying processes can reduce cyanide level in cassava. Decrease in cyanide level due to those processes can be related to the dissolved of cyanide formed during the fermentation with water during pressing process, in which it is related to the property of cyanide that water soluble [7].

Drying process is also has influence in decreasing the level of cyanide in raw material for cyanide will evaporate during the process. Cyanide is chemical solution containing $\mathrm{CN}$ group with triple carbon atom bound to nitrogen atom. Cyanide is non-colorful solution, very toxic and easy to evaporate in room temperature of $26{ }^{\circ} \mathrm{C}$. Hydrogen cyanide is a weak acid and it turns into $\mathrm{CN}^{-}$ion in a solution containing water. Drying process was conducted using cabinet with temperature of $60{ }^{0} \mathrm{C}$ for approximately 6 hours. Therefore, using high temperature for drying, cyanide formed during fermentation process will evaporate since the temperature is higher than the boiling point of cyanide [4].

Cassava flour resulted from 72 hours fermentation process of $17.64 \mathrm{ppm} / \mathrm{bk}$ is within the safe limit for consumption based on quality requirement of SNI 01-2997-1992 for cassava flour since the cyanide acid level is under $40 \mathrm{ppm} / \mathrm{bk}$. The level of cyanide in a body that exceeds the safe limit can have dangerous toxic effect. When consuming cassava without removing linamarin residue and its fractions, inside a body, linamarin can be dissolved by linamarase resulted in by bacteria in digestive tract and releasing cyanide [3]. Compare to its precursor, the toxicity of cyanide is stronger [7]. The decrease percentage of cyanide level in cassava after fermentation is increasing with the increasing period of fermentation. It is related to the breakdown of cyanogenicglucoside during fermentation by linamarase enzyme and $\beta$ glucosidase either in cassava tuber or resulted by microorganism. Total mold is increasing along with the decrease in cyanide level in cassava [6]. With the increasing of total mold, the number of $\beta$-glucosidase enzyme resulted by mold is increasing; therefore, process of cyanide breakdown into cyanide acid ( $\mathrm{HCN})$ will be increasing. Higher HCN released causes lower cyanide level in cassava.

The decrease percentage of cyanide level in cassava flour is fluctuate due to the influence of pressing and drying processes and it is related to water level in material after fermentation in which cyanide is water soluble and easy to decompose in higher temperature [6]. HCN level contained in gaplek and cassava flour is under $50 \mathrm{mg} / \mathrm{kg}$. It indicates that submerging and drying are efficient in decreasing the level of HCN. In addition, peeling the cassava tuber and pressing it using mechanic press has able to decrease cyanide level up to $33 \%$ [5].

Sagu lempeng is made from cassava flour resulted from fermentation of half wet or half dry cassava. The resulted sagu lempeng contains carbohydrate total of $86.9 \mathrm{~g}$ but low protein level. Societies in North Maluku, in general, consume sagu lempeng as their main food, a substitution to rice. Sagu lempeng is chosen more to the texture value of the product. The use of good fermentation method can determine whether or not sagu lempeng is safe to consume as a main food or snack.

\section{CONCLUSIONS}

Cassava flour resulted from 72 hours fermentation process of $17.64 \mathrm{ppm} / \mathrm{bk}$ is within the safe limit for consumption based on quality requirement of SNI 01-2997-1992 for cassava flour since the cyanide acid level is under $40 \mathrm{ppm} / \mathrm{bk}$. Sagu lempeng is made from cassava flour resulted from fermentation of half wet or half dry cassava. The resulted sagu lempeng contains carbohydrate total of $86.9 \mathrm{~g}$ but low protein level.

\section{ACKNOWLEDGMENT}

Many thanks to BPTP North Maluku Province as the provider of basic material has developed the loccal variety of Ternate cassava. Dirjen DIKTI that has given fund during the time of education and research. The Regency Government of Sula Archipelago that has also given the fund to smoothen the process of accomplishing the research.

\section{REFERENCES}

[1] Asegbeloyin JN, and Onyimonyi AE, 2007. The Effect of Different Processing Methods on the Residual Cyanide of 'Gari'. Journal of Nutrition, Pakistan, 6 (2): 163-166.

[2] BPS Maluku Utara, 2010. Maluku Utara Dalam Angka. Buku Laporan Pemerintah Provinsi Maluku Utara. Ternate.

[3] Cardoso,AP., Mirione, 2005. Prosesing of Cassava Roots to Remove Cyanogens. Journal of Food Composition and Analysis 18,P. 451460.

[4] Cereda, M.P. and Mattos, M.C.Y. (1996). "Linamarin - The Toxic Compound of Cassava". Journal of Venomous Animals and Toxins (online) 2 (1), 6-12; ISSN 0104-7930.

[5] Ginting, E., and Yudi, W. 2003. Cyanide Reduction in Cassava Root Products Through Processing and Selection of Cultivars in Relation to Food Safety. Procceeding International Seminar Investment Opportunity on Agribussinnes in Perapective of Food Safety and Bioterrorism Act ISBN 979-3560-4-3.

[6] Perera CO, 2010. Removal of Cyanogenic Glycoside from Cassava during Controlled Drying, Drying Technology, 28: 68-72.

[7] Siritunga, D and R.T. Sayre, 2003. Generation of Cyanogen-Free Transgenic Cassava. Departement of Plant Biology the Ohio State University. Ohio 